\title{
First report of Verticillium dahliae race 2 on scarlet eggplant in Brazil
}

\author{
Alba Suaste-Dzul ${ }^{1} \cdot$ Josiene Silva Veloso ${ }^{1} \cdot$ Ailton Reis $^{2}(\mathbb{0}$ \\ Received: 5 October 2020 / Accepted: 18 January 2021 / Published online: 25 January 2021 \\ (c) Società Italiana di Patologia Vegetale (S.I.Pa.V.) 2021
}

Keywords Solanum aethiopicum var. gilo $\cdot$ Verticillium wilt $\cdot$ Pathogen variability

Verticillium wilt is an important disease of Solanum spp. vegetables in Brazil, including the scarlet eggplant, Solanum aethiopicum var. gilo. Grown especially by small holder farmers, this vegetable is greatly appreciated in Southeastern Brazil. In 2008 and 2009, some scarlet eggplants exhibiting symptoms of wilt, leaf chlorosis, and vascular discoloration were collected in three commercial fields in Rio de Janeiro (RJ), Ceará (CE) and Goiás (GO) states, Brazil. Disease incidence was around $40 \%, 12 \%$ and $65 \%$ in RJ, CE and GO fields, respectively. Fungal isolates presenting verticillate conidiophores and microesclerotia were obtained from all sampled plants and cultivated on potato dextrose agar (PDA) medium. Based on morphological characteristics, three isolates were identified as Verticillium sp. They were deposited in the plant pathogenic fungal collection of the EMBRAPA vegetables: Vert110, Vert111, and Vert117. The nuclear rDNA internal transcribed spacers (nrITS) was sequenced (GenBank accession numbers: MW051677, MW051678, and MW051679, respectively) and compared to other Verticillium species. A query of our sequences against the GenBank showed 100\% similarity $(\mathrm{e}$-value $=0)$ to Verticillium dahliae strains. A maximum likelihood phylogenetic analysis, including previously published sequences (Inderbitzin et al. 2011), grouped the isolates with $V$. dahliae with $100 \%$ bootstrap support. Pathogenicity assays were performed with scarlet eggplant seedlings, in addition to a set of race differential cultivars of tomato: "Ponderosa (PD)" (susceptible to races 1 and 2) and "Floradade (FD)" (resistant to race 1). Wilt symptoms on lower leaves were first observed in all inoculated scarlet eggplant seedlings after 18-23 days, except on control plants. In addition, all isolates were able to induce wilt symptoms on "PD" and "FD" cultivars, revealing them as race 2 . The same fungi were re-isolated from all inoculated plants. Fungal Race identity was confirmed with molecular analysis using Ave1F/Ave1R and VdR2f/VdR2r primers, specific to race 1 and 2, respectively (Short et al. 2014; Usami et al. 2017). This is the first report of $V$. dahliae race 2 causing verticillium wilt on scarlet eggplant in Brazil.

Funding This work was supported by EMBRAPA Vegetables and CAPES.

\section{References}

Inderbitzin P, Bostock RM, Davis RM, Usami T, Platt HW, Subbarao KV (2011) Phylogenetics and taxonomy of the fungal vascular wilt pathogen Verticillium, with the descriptions of five new species. PLoS ONE 6(12):e28341

Usami T, Momma N, Kikuchi S, Watanabe H, Hayashi A, Mizukawa M, Yoshino K, Ohmori Y (2017) Race 2 of Verticillium dahliae infecting tomato in Japan can be split into two races with differential pathogenicity on resistant rootstocks. Plant Pathol 66:230-238(invert the sequence of this reference with Short et al. - Short et al. should came before Usami et al.)

Short DPG, Gurung S, Maruthachalam K, Atallah Z, Subbarao KV (2014) Verticillium dahliae race 2-specific PCR reveals a high frequency of race 2 strains in commercial spinach seed lots and delineates race structure. Phytopathology 104(7):779-785

Publisher's Note Springer Nature remains neutral with regard to jurisdictional claims in published maps and institutional affiliations.

Ailton Reis

ailton.reis@embrapa.br

1 Universidade Federal Rural de Pernambuco - UFRPE, Recife - PE, Brazil

2 EMBRAPA Vegetables, Plant Pathology Laboratory, Embrapa Hortaliças, Brasília, DF, Brazil 